\title{
Effects of Fish Stocking Density on Water Quality, Growth Performance of Tilapia and Yield of Butterhead Lettuce Grown in Decoupled Recirculation Aquaponic Systems
}

\author{
Abdel Razzaq Al Tawaha ${ }^{1 *}$, Puteri Edaroyati Megat Wahab' ${ }^{1}$, Hawa Binti Jaafar ${ }^{1}$, \\ Ali Tan Kee Zuan², Mohd Zafri Hassan³ \\ 1 Department of Crop Science, Faculty of Agriculture, Universiti Putra Malaysia, 43400 UPM Serdang, Selangor, \\ Malaysia \\ 2 Department of Land Management, Faculty of Agriculture, Universiti Putra Malaysia, 43400 UPM Serdang, \\ Selangor, Malaysia \\ 3 Department of Aquaculture, Faculty of Agriculture, Universiti Putra Malaysia, 43400 UPM Serdang, Selangor, \\ Malaysia \\ * Corresponding author's e-mail: abdelrazzaqaltawaha@gmail.com
}

\begin{abstract}
This study was conducted over a period of 52 days to determine the effects of fish stocking density on the water quality, growth performance of tilapia and yield of butterhead lettuce cultivated in decoupled recirculation aquaponic systems (DRAPS). In this study, three respective tilapia stocking densities (treatments) of $8 \mathrm{~kg} \cdot \mathrm{m}^{-3}, 10 \mathrm{~kg} \cdot \mathrm{m}^{-3}$, and $12 \mathrm{~kg} \cdot \mathrm{m}^{-3}$ were used to evaluate the butterhead lettuce in the DRAPS, which consist of two independent loops. All treatments were done in triplicates. The results showed with increased stocking density, the electrical conductivity, total dissolved substances and salinity increased and dissolved oxygen decline. The results showed that the highest stocking density produced the highest nutrients accumulation of ammonia-nitrogen $\left(\mathrm{NH}_{3}-\mathrm{N}\right)$, ammonium $\left(\mathrm{NH}_{4}\right)$, nitrite-nitrogen $\left(\mathrm{NO}_{2}-\mathrm{N}\right)$ and nitrate-nitrogen $\left(\mathrm{NO}_{3}-\mathrm{N}\right)$ and potassium $(\mathrm{K})$ except for phosphorus $(\mathrm{P})$. Nevertheless, based on the conversion of fish feed to $\mathrm{NO}_{3}-\mathrm{N}$ and $\mathrm{P}$ per kilogram of feeds, the lowest stocking density provided the highest concentration of $\mathrm{NO}_{3}-\mathrm{N}$ and $\mathrm{P}$. It was documented that DRAPS relied solely on the fish waste produced an insufficient concentration of N, P, K and iron. The average survival rate of tilapia in all treatments was above $94 \%$ and was not a significant difference among the treatments.
\end{abstract}

Keywords: Decoupled aquaponics systems, stocking density, tilapia, butterhead lettuce (Lactuca sativa).

\section{INTRODUCTION}

Aquaponics system (APS) is a modern agricultural technique that provides a more sustainable food production system through a synergistic combination of recirculation aquaculture system (RAS) (Love et al. 2015) and hydroponic (HP) (Resh 2012) where the biological processes in the system produce nitrogen $(\mathrm{N})$ in the form of nitrate $\left(\mathrm{NO}_{3}\right)$ as the main end product (Graber and Junge 2009; Rakocy et al. 2006; Rakocy 2012). However, integration tilapia and lettuce being as one of the most significant integrations in APS and the success of this symbiotic plays a crucial role in improving the sustainability of the agriculture production system (Ajitama et al. 2018; Jordan et al. 2018a; 2018b; Sreejariya et al. 2016).

The concentrations of macronutrients such as $\mathrm{N}$, phosphorus $(\mathrm{P})$, and potassium $(\mathrm{K})$ produced through the breakdown of fish waste in APS are inadequate compared to the levels of nutrients in HP systems (Rakocy et al. 2004). Several studies reported that the levels of nutrients in APS were inadequate as the ratio of the fish and plants was imbalanced, resulting in $\mathrm{NO}_{3}$ depletion (Buzby and Lin. 2014). Studies also showed that 
an imbalance ratio of fish and plants might lead to the accumulation of $\mathrm{NO}_{3-}$ (Liang and Chien 2013). Therefore, stocking density should be optimal to maintain suitable water quality for fish and plant growth as well as the proper functioning of the system.

There were a few studies reported the integration of tilapia and lettuce in the DRAPS (Delaide et al. 2016). In 2015, a German professor, Kloas, conducted the first study on the integration of tomato and tilapia in DRAPS using the nutrient film technique (NFT) HP unit. Then, a few other studies were conducted to evaluate the efficiency of DRAPS by integrating tilapia and tomatoes (Karimanzira et al. 2016), or African catfish and tomato (Suhl et al. 2018a), tilapia and lettuce (Monsees et al. 2019), tilapia and cucumber (Blanchard et al. 2020). However, Suhl et al. (2016) reported that the fish to plant ratio and the production of the nutrients were not optimized to integrate different species of both fish and plants in DRAPS. To date, there were limited studies on DRAPS (Monsees et al. 2019; Suhl et al. 2018b) and no study on the effects of fish stocking density on the lettuce growth and production. Nevertheless, according to previous studies, different plants and fishes will have a different optimal ratio and are highly dependent on factors such as fish stocking density, APS type, plant species, planting density, type of HP or soilless culture production system, water flow rate, and external factors such as light, air, water temperature, and $\mathrm{pH}$. However, the data generated in this study can be used to estimate the optimal fish ratio to obtain an adequate range of $\mathrm{N}$ level for high growth of lettuce and to further support the importance of DRAPS as the new sustainable agriculture production system. The data is also important for the generation of the baseline data on the applicability of DRAPS in tropical regions as a small-scale production in order to improve food security, reduce poverty, and maximize the availability of fish and plants to the economy of the country.

There were two objectives in this study: (I) to determine the ideal stocking density of tilapia (Oreochromis niloticus) and its effects on the water quality, growth performance of fish, and yield of lettuce (Lactuca sativa) in the DRAPS with non-controlled conditions and without the addition of inorganic fertilizers and (II) to determine the composition of nutrients, which produced through the biological processes (fish metabolism) under the non-controlled condition, in the solution.

\section{MATERIALS AND METHODS}

\section{The setting of DRAPS}

This study was conducted in a shelter at Ladang 15, Faculty of Agriculture, UPM Serdang, Selangor, Malaysia (longitude $101^{\circ} 44^{\prime} \mathrm{N}$ and latitude $2^{\circ} 58^{\prime} \mathrm{S}, 68 \mathrm{~m}$ above sea level). The total area involved was $85 \mathrm{~m}^{2}$ This study was carried out under the tropical temperature range between $26^{\circ} \mathrm{C}$ and $37^{\circ} \mathrm{C}$. The DRAPS used in this study was adapted from the system developed by Kloas et al. (2015), which is composed of two loops, with slight modification done to the system, as illustrated in Figure 1.

\section{Water circulation in DRAPS}

The setting of the first loop was adapted from Rakocy (2007). The water circulation in the first loop started from a single $350 \mathrm{~L}$ fish tank and was then connected to a $45 \mathrm{~L}$ mechanical filtering tank to remove solid particles and minimize floating debris as much as possible so that the aggregate formation would not impact the yield of the fish and plants in the system. After the mechanical filtering stage, the filtered water flowed to a 45 L biofilter tank, which contained bio balls and bio rings filter materials for the biological processes (nitrification) to take place. From the biofilter tank, the water was then connected to a $300 \mathrm{~L}$ sump tank for the collection of nitrified water and to complete the first loop. The total volume for the first loop was $740 \mathrm{~L}$ with a flow rate of $9.2 \mathrm{~m}^{3} \cdot \mathrm{day}^{-1}$ or $6.4 \mathrm{~L} \cdot \mathrm{min}^{-1}$ (Endut et al. 2010), which enabled the water retention time of 50 minutes in the fish tank. The second loop of the DRAPS used in this study was based on the setup design by Kloas et al. (2015). It received the nutrient solution from the first loop and was then connecting the nutrient solution to an additional reservoir with a one-way-valve, which made the water in the DRAPS recirculated independently in one direction from the first loop to the HP unit in the second loop. The additional $300 \mathrm{~L}$ tank or reservoir was connected to an NFT HP. The flow rate of the circulation in the second 


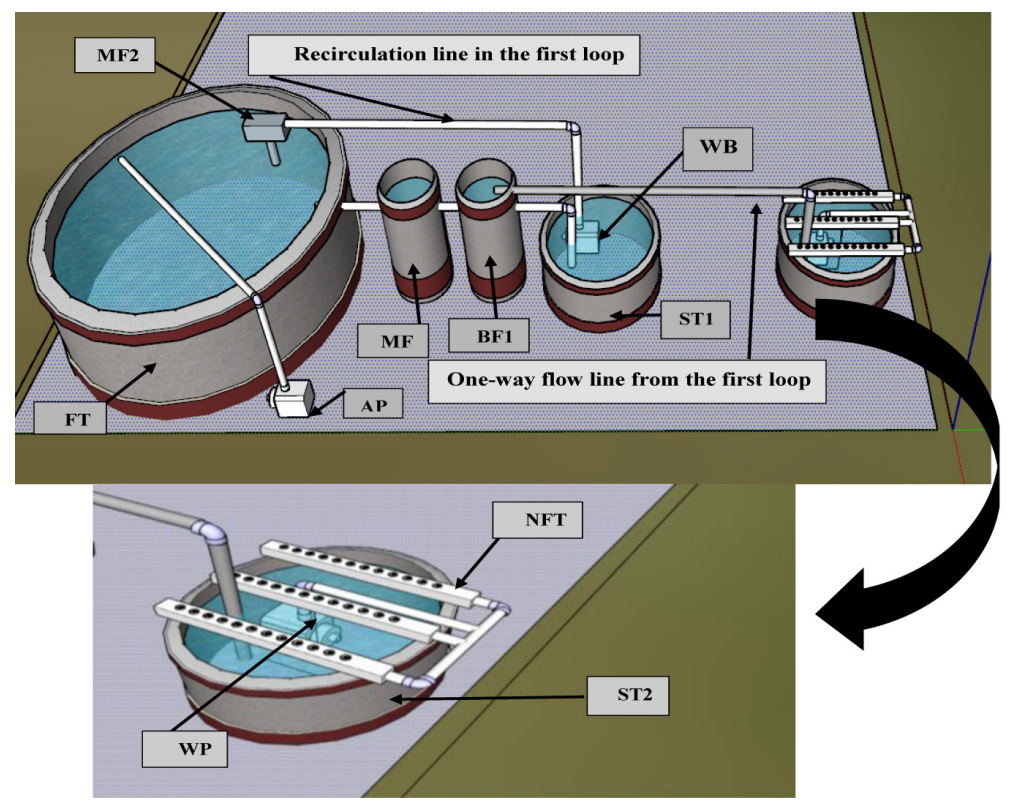

Figure 1. A schematic illustration of NFT of original DRAPS was used in Universiti Putra Malaysia. (AP) Air pump, (FT) fish tank, (MF) mechanical filter, (BF) biological filter, (ST1) sump tank 1, (WP) water pump, (MF2) mechanical filter 2. The second loop is composed; (NFT) hydroponics unit (NFT trials), (ST2) sump tank 2,

(WP) water pump

loop was between one to two liters per minute (Resh 2013). The total volume of water in the first and second loops of the DRAPS was maintained at $1040 \mathrm{~L}$. There was no water discharge during the experimental period except for the water lost through evaporation, transpiration, and sludge removal at less than 5\% under tropical conditions.

\section{Plant and fish materials}

The butterhead lettuce (Lactuca sativa) seeds were obtained from a company known as (Green World Genetics). The lettuce seeds were sown and grown in a seed tray for 14 days before the transplantation to match the size of seedlings at the time of planting. The seeds were watered daily until it starts to germinate. After two weeks, the germinated lettuces were then transferred to the HP cups. The seedlings from the third to fourth true-leaf stages (14 days old) were shifted to the NFT HP with a planting density of 32 plants $\mathrm{m}^{-2}$ and with a spacing of $15 \times 15 \mathrm{~cm}^{2}$. No external factors such as the usage of fertilizers were introduced to the DRAPS, both air and water temperature were also not controlled in the study. The red tilapia (Oreochromis niloticus) used in this study were obtained from the aquaculture farm in UPM in
Puchong, where the tilapia were grown in a conventional aquaculture system. All the red tilapia with an initial average weight of $125 \pm 20 \mathrm{~g}$ were stocked simultaneously in all nine of the DRAPS. The daily feeding rate for each stocking density of tilapia in the DRAPS was $2 \%$ of the bodyweight of tilapia. The feed type was a commercial floating pellet with a size of $3.2 \mathrm{~mm}$ from Dindings Company. The proximate nutrient composition of the fish feed was $32 \%$ protein, $5 \%$ fat, $10 \%$ ash, $5 \%$ fiber, and $10 \%$ moisture content. The fish were fed twice a day manually for 30 minutes at 9.00 and $5.00 \mathrm{pm}$.

\section{Experimental design set up and treatments}

The period for completing this study was 52 days, starting from April 6, 2019, until May 16, 2019. However, including the time taken for the establishment of the study site and system set up for this study, the total period for the completion of this study was 120 days. The completely Randomized Complete Block Design (RCBD) with three replicates was used in this study. The stocking densities were determined based on the minimum density required to provide sufficient $\mathrm{N}$ for the growth of butterhead lettuce in a small-scale APS. A total of nine independent DRAPS, which consisted of three fish stocking 
densities, were set up, with three replicates for each fish stocking density. The stocking densities (treatments) of $12 \mathrm{~kg} \cdot \mathrm{m}^{-3}, 10 \mathrm{~kg} \cdot \mathrm{m}^{-3}$, and $8 \mathrm{~kg} \cdot \mathrm{m}^{-3}$ were used in this study and assigned as T1, T2, and T3. The stock densities per $350 \mathrm{~L}$ fish tank were $4.2 \mathrm{~kg} \cdot \operatorname{tank}^{-1}, 3.5 \mathrm{~kg} \cdot \operatorname{tank}^{-1}$, and $2.8 \mathrm{~kg} \cdot \operatorname{tank}^{-1}$, respectively. Each stocking density had three replicates and each replicate was connected to an HP unit. This gave a total of nine HP units and each HP unit have three troughs of NFT. The experiment was conducted under a 12-h light (07.00-17.00 h)/12-h dark (17.00$07.00 \mathrm{~h}$ ) natural light cycle

\section{Measurement of water quality paraments}

Various parameters were measured and recorded on a daily and weekly basis as an indication of the water quality. The dissolved oxygen (DO; $\left.\mathrm{mg} \cdot \mathrm{L}^{-1}\right)$, oxygen saturation (\%), temperature $\left(\mathrm{T} ;{ }^{\circ} \mathrm{C}\right), \mathrm{pH}$, electric conductivity $(\mathrm{EC} ; \mathrm{mS}$ $\mathrm{cm}^{-1}$ ), total dissolved solids (TDS; $\mathrm{g} \mathrm{L}^{-1}$ ), and salinity (S; ppt) of the water in the fish tanks and HP units were measured daily using a YSI 556 Multiparameter meter (YSI Inc. USA) before feeding the fish at 9 am and $4 \mathrm{pm}$. The aquarium thermostat heaters did not use for controlling the $\mathrm{T}$ of the fish tanks and HP units. The $\mathrm{pH}$ and EC in both the fish tanks and HP units were also not controlled throughout the study. Therefore, the concentrations of ammonia-nitrogen $\left(\mathrm{NH}_{3}-\mathrm{N}\right)$ (Silva et al. 2017), ammonium $\left(\mathrm{NH}_{4}\right)$ (Geisenhoff et al. 2016) nitrate-nitrogen $\left(\mathrm{NO}_{2}-\mathrm{N}\right)(\mathrm{Em}-$ erson et al. 1975) in each of the fish tanks were frequently measured (in terms of $\mathrm{mg} \mathrm{L}^{-1}$ ). In addition, parameters such as nitrate-nitrogen $\left(\mathrm{NO}_{3}-\right.$ $\mathrm{N})$, orthophosphate $\left(\mathrm{PO}_{4}-\mathrm{P}\right)$, potassium $(\mathrm{K})$, iron $(\mathrm{Fe})$, calcium $(\mathrm{Ca})$, and alkalinity $\left(\mathrm{CaCO}_{3}\right.$ $\mathrm{mg} \mathrm{L}^{-1}$ ) were analyzed at the beginning and the end of the study using a multiparameter spectrophotometer (HI 83200, HANNA instruments, Woonsocket, RI, USA).

\section{Growth and yield measurements of lettuce}

Fresh yields of the lettuce were measured at the harvest stage. The lettuce samples were divided into leaf, stem and root and weighted by using a ME analytical Weighing Balance (Mettler Toledo Inc.). The number of leaves was determined by counting the total number of leaves per plant at the harvest stage. Total leaf area was measured using a leaf area meter (Li-Cor LI$3100 \mathrm{C})$ at the harvest stage. The leaves were cut off from the stem and entered to leaf area meter and the reading showed on the screen recorded in square centimeters $\mathrm{cm}^{2}$.

\section{Growth and yield characteristics of tilapia}

The health condition and mortality rate of the tilapia were monitored twice a day, which were in the morning and evening. The data of this study were categorized into two categories. The first category was the initial measurements that were recorded at the beginning of the study, and this included the initial stocking densities $\left(\mathrm{kg} \cdot \mathrm{m}^{-3}\right)$. The second category of data was recorded at the end of this study, which included the final stocking density $\left(\mathrm{kg} \cdot \mathrm{m}^{-3}\right)$, weight gain (WG; \%), fish increment (\%), feed conversion ratio (FCR), and survival rate (SR; \%). The tilapia from all nine of the treatment tanks were weighted in order to compare the growth rate and yield of the tilapia. Furthermore, the growth performances of the tilapia and the feed utilization were calculated as described by Sveier et al. (2000) and Jimoh et al. (2019) using the following formulas.

The WG was estimated using the following formula.

$$
\mathrm{WG}=\text { final fish weight }(g)-\text { initial fish weight }(g)
$$

The FCR was calculated using the following formula.

$$
\mathrm{FCR}=\frac{\text { weight of feed given }(g)}{\text { fish weight gain }(g)}
$$

The SR was calculated with the following formula.

$$
\text { SR }(\%)=100 \times \frac{(\text { final number of fish survived }}{\text { total number of fish stocked })}
$$

\section{Statistical analysis}

The RCBD with three replicates was used in this study. The data were analyzed using analysis of variance (ANOVA) in the Statistical Analysis System (SAS), version 9.4 (SAS Institute Inc., Cary, NC, USA). The means were compared using the least significant difference (LSD) test with a significance level of 0.05 . 


\section{RESULTS}

\section{Physical water parameters of fish tank}

The physical water parameters such as water $\mathrm{T}, \mathrm{pH}, \mathrm{DO}, \mathrm{EC}, \mathrm{TDS}$ and salinity in all the treatment tanks are presented in Table 1. There was no significant difference in the $\mathrm{T}$ and $\mathrm{pH}$ among all the treatment tanks $(p>0.05)$. However, there was a significant difference $(\mathrm{p}<0.05)$ in the DO among the treatments, with the lowest mean of DO observed in T1, which had the highest stocking density (Table 1). The EC was also significantly different among the treatments $(\mathrm{p}<0.05)$, with mean values of $0.367 \mathrm{~ms} \cdot \mathrm{cm}^{-1}, 0.362 \mathrm{~ms} \cdot \mathrm{cm}^{-1}$, and $0.326 \mathrm{~ms} \cdot \mathrm{cm}^{-1}$ for $\mathrm{T} 1, \mathrm{~T} 2$, and $\mathrm{T} 3$, respectively. Moreover, the TDS was significantly higher in T1 and T2, as compared to that of T3 (Table 1). Finally, the average salinity of the water was also significantly higher in $\mathrm{T} 1$ and $\mathrm{T} 2$ as compared to that of T3, which were $0.166 \mathrm{ppt}, 163 \mathrm{ppt}$, and $0.146 \mathrm{ppt}$, respectively. It has been documented that with increased stocking density, the EC, TDS and salinity increased and DO decrease.

Values reported are mean for three replications. Mean values $\pm(S D)$ with a different letter in the same row are significantly different $(\mathrm{p}<0.05)$.

\section{Chemical water parameters of fish tanks}

Chemical water parameters were monitored and recorded in Table 2 . The mean \pm standard deviation (SD) values for the $\mathrm{N}$ compounds such as $\left(\mathrm{NH}_{3}-\mathrm{N}\right),\left(\mathrm{NH}_{4}^{+}\right),\left(\mathrm{NO}_{2}-\mathrm{N}\right)$, and $\mathrm{NO}_{3}-\mathrm{N}, \mathrm{PO}_{4}^{-}$ $\mathrm{P}, \mathrm{K}, \mathrm{Ca}$, and $\mathrm{Fe}$ that were measured throughout the study are presented in Table 2. The differences in the concentrations of $\mathrm{NH}_{3}-\mathrm{N}, \mathrm{NH}_{4}^{+}$, and $\mathrm{NO}_{2}-\mathrm{N}$ were insignificant $(\mathrm{p}>0.05)$ among the treatments, but the concentrations increased in higher stocking density. However, the difference in $\mathrm{NO}_{3}-\mathrm{N}$ concentration was significant $(\mathrm{p}<0.05)$ between all three treatments. $\mathrm{T} 1$ had the highest concentration of $\mathrm{NO}_{3}-\mathrm{N}$, whereas $\mathrm{T} 3$ had the lowest concentration of $\mathrm{NO}_{3}-\mathrm{N}$ (Table 2). The percentage of nutrient reduction $\left(\mathrm{NH}_{3}-\mathrm{N}, \mathrm{NH}_{4}^{+}\right.$and $\mathrm{NO}_{2}-\mathrm{N}$ ) in the stocking density treatments were relatively decreased when increasing stocking density. The concentrations of $\mathrm{PO}_{4}-\mathrm{P}, \mathrm{Ca}$, and $\mathrm{Fe}$ were not significantly different among all three treatments, except for $\mathrm{K}^{+}(\mathrm{p}<0.05)$. In addition, The $\mathrm{Ca}$ and the alkalinity values were not significantly different among all the treatments $(\mathrm{p}>0.05)$ (Table 2). Finally, it has been observed that the concentration $\mathrm{NH}_{3}-\mathrm{N}, \mathrm{NH}_{4}^{+}, \mathrm{NO}_{2}-\mathrm{N}$ and $\mathrm{NO}_{3}-\mathrm{N}$

Table 1: Physical water parameters of tilapia tanks in response to different stocking densities in DRAPS conditions during the study period

\begin{tabular}{|c|c|c|c|}
\hline \multirow{2}{*}{ Physical water parameters } & \multicolumn{3}{|c|}{ Treatments } \\
\cline { 2 - 4 } & $\mathrm{T} 1$ & $\mathrm{~T} 2$ & $\mathrm{~T}$ \\
\hline $\mathrm{T}\left({ }^{\circ} \mathrm{C}\right)$ & $28.39 \pm 1.38 \mathrm{a}$ & $28.10 \pm 1.48 \mathrm{a}$ & $6.36 \pm 1.45 \mathrm{a}$ \\
\hline $\mathrm{pH}$ & $6.89 \pm 0.20 \mathrm{a}$ & $6.92 \pm 0.17 \mathrm{a}$ & $4.76 \pm 0.72 \mathrm{a}$ \\
\hline $\mathrm{DO}\left(\mathrm{mg} \mathrm{L}^{-1}\right)$ & $4.44 \pm 0.79 \mathrm{~b}$ & $4.78 \pm 0.71 \mathrm{a}$ & $0.326 \pm 0.049 \mathrm{~b}$ \\
\hline $\mathrm{EC}\left(\mathrm{ms} \mathrm{cm}^{-1}\right)$ & $0.368 \pm 0.073 \mathrm{a}$ & $0.362 \pm 0.066 \mathrm{a}$ & $0.203 \pm 0.035 \mathrm{~b}$ \\
\hline TDS $\left(\mathrm{g} \mathrm{L}^{-1}\right)$ & $0.229 \pm 0.046 \mathrm{a}$ & $0.227 \pm 0.050 \mathrm{a}$ & $0.146 \pm 0.026 \mathrm{~b}$ \\
\hline Salinity $(\mathrm{ppt})$ & $0.166 \pm 0.035 \mathrm{a}$ & $0.163 \pm 0.031 \mathrm{a}$ & \\
\hline
\end{tabular}

Table 2: Chemical water parameters of tilapia tanks in response to different stocking densities in DRAPS conditions during the study period

\begin{tabular}{|c|c|c|c|}
\hline \multirow{2}{*}{ Chemical water parameters } & \multicolumn{3}{|c|}{ Treatments } \\
\hline & T1 & T2 & T3 \\
\hline $\mathrm{NH}_{3}-\mathrm{N}\left(\mathrm{mg} \mathrm{L}^{-1}\right)$ & $2.09 \pm 2.02 a$ & $1.32 \pm 1.02 \mathrm{ab}$ & $0.99 \pm 0.73 b$ \\
\hline $\mathrm{NH}_{4}\left(\mathrm{mg} \mathrm{L}^{-1}\right)$ & $2.58 \pm 2.47 a$ & $1.58 \pm 1.17 a b$ & $1.24 \pm 0.87 \mathrm{~b}$ \\
\hline $\mathrm{NO}_{2}-\mathrm{N}\left(\mathrm{mg} \mathrm{L}^{-1}\right)$ & $1.80 \pm 3.80 a$ & $1.53 \pm 3.22 \mathrm{a}$ & $1.40 \pm 2.92 a$ \\
\hline $\mathrm{NO}_{3}-\mathrm{N}\left(\mathrm{mg} \mathrm{L}^{-1}\right)$ & $36.7 \pm 3.70 \mathrm{a}$ & $30.77 \pm 2.2 b$ & $26.13 \pm 0.25 b$ \\
\hline $\mathrm{PO}_{4}-\mathrm{P}\left(\mathrm{mg} \mathrm{L}^{-1}\right)$ & $15.53 \pm 3.07 a$ & $15.83 \pm 2.25 a$ & $19.13 \pm 7.14 a$ \\
\hline $\mathrm{K}\left(\mathrm{mg} \mathrm{L}^{-1}\right)$ & $22.06 \pm 3.43 a$ & $22.66 \pm 1.52 a$ & $13.81 \pm 2.16 b$ \\
\hline $\mathrm{Ca}\left(\mathrm{mg} \mathrm{L}^{-1}\right)$ & $107 \pm 16 a$ & $109 \pm 21.28 a$ & $98.67 \pm 45.08 a$ \\
\hline $\mathrm{Fe}\left(\mathrm{mg} \mathrm{L}^{-1}\right)$ & $0.10 \pm 0.047 a$ & $0.08 \pm 0.03 a$ & $0.10 \pm 0.020 a$ \\
\hline Alkalinity $\left(\mathrm{CaCO}_{3} \mathrm{mg} \mathrm{L}^{-1}\right)$ & $59 \pm .36 .5 a$ & $37.33 \pm 1.52 a$ & $63.67 \pm 16.50 a$ \\
\hline
\end{tabular}


and $\mathrm{K}$ increased with increased stocking density, while $\mathrm{P}$ decreased.

Values reported are mean for three replications. Mean values $\pm(S D)$ with a different letter in the same row are significantly different $(p<0.05)$.

\section{Physical water parameters of hydroponic units}

Table 3 reports the descriptive statistics of water quality parameters for HP units in different treatments. In this study, the $\mathrm{T}$ in the morning and evening, $\mathrm{pH}, \mathrm{DO}$, TDS and salinity varied within a small range and were insignificantly different $(\mathrm{P}>0.05)$ among the treatments.

Values reported are mean for three replications. Mean values $\pm(S D)$ with a different letter in the same row are significantly different $(\mathrm{p}<0.05)$.

\section{Lettuce growth performance}

Table 4 shows the potential of using the nutrient solution from the fish tank to support the growth and production of lettuce. The results showed significant differences $(p<0.05)$ in the shoot fresh weight and root fresh weight except for the number of leaves and leaf area. The shoot fresh weight at $\mathrm{T} 1$ and $\mathrm{T} 2$ were significantly decreased by $23.3 \%$ than $\mathrm{T} 2$. In contrast, the root fresh weight at $\mathrm{T} 1$ and $\mathrm{T} 2$ were significantly reduced by $77.2 \%$ and $72.7 \%$ than $\mathrm{T} 3$.
Values reported are mean for three replications. Mean values $\pm(\mathrm{SD})$ with a different letter in the same row are significantly different $(\mathrm{p}<0.05)$.

\section{Fish growth performance}

The growth performances of tilapia are shown in Table 5. The results of the statistical analysis using one-way ANOVA showed that the differences in the final weight, weight gain and feed conversion ratio of tilapia among the stocking density treatments were significant $(p<0.05)$. The mean of the final biomass of tilapia in $\mathrm{T} 1$ was higher than that in $\mathrm{T} 2$ and $\mathrm{T} 3$, respectively (Table 5). The highest weight gain was found in $\mathrm{T} 1$, whereas the lowest was found in T3. The results also showed that lower FCR were obtained from T3 and T2, respectively. There is no significant difference $(\mathrm{P}>0.05)$ in the $\mathrm{SR}$ of tilapia was observed among all the treatments.

Values reported are mean for three replications. Mean values $\pm(\mathrm{SD})$ with a different letter in the same row are significantly different $(\mathrm{p}<0.05)$.

The amount of nitrate per $1,000 \mathrm{~g}$ of feeds is shown in Figure 2. The results showed that a higher $\mathrm{NO}_{3}-\mathrm{N}$ concentration per $1,000 \mathrm{~g}$ of feeds, which was $9.12 \mathrm{mg} \cdot \mathrm{L}^{-1}$, was obtained from $\mathrm{T} 3$, followed by $8.45 \mathrm{mg} \cdot \mathrm{L}^{-1}$ and $8.40 \mathrm{mg} \cdot \mathrm{L}^{-1}$ from $\mathrm{T} 2$ and $\mathrm{T} 1$, respectively. Also, the results showed that a higher $\mathrm{P}$ concentration was $2.13 \mathrm{mg} \cdot \mathrm{L}^{-1}$, was obtained from $\mathrm{T} 3$, followed by $1.41 \mathrm{mg} \cdot \mathrm{L}^{-1}$ and $1.15 \mathrm{mg} \cdot \mathrm{L}^{-1}$ from $\mathrm{T} 2$ and $\mathrm{T} 1$. The overall view of Figure 6 , that low stocking density yields higher $\mathrm{NO}_{3}-\mathrm{N}$ and $\mathrm{P}$.

Table 3: Physical water quality parameters in the hydroponic tank in response to different stocking densities in DRAPS conditions

\begin{tabular}{|c|c|c|c|}
\hline \multirow{2}{*}{ Parameters } & \multicolumn{3}{|c|}{ Treatments } \\
\cline { 2 - 4 } & $\mathrm{T} 1$ & $28.01 \pm 0.86 \mathrm{a}$ & $\mathrm{T}$ \\
\hline $\mathrm{T}\left({ }^{\circ} \mathrm{C}\right)$ morning & $28.06 \pm 0.98 \mathrm{a}$ & $31.80 \pm 1.03 \mathrm{a}$ & $31.76 \pm 0.87 \mathrm{a}$ \\
\hline $\mathrm{T}\left({ }^{\circ} \mathrm{C}\right)$ evening & $31.69 \pm 0.97 \mathrm{a}$ & $7.28 \pm 0.42 \mathrm{a}$ & $7.29 \pm 0.40 \mathrm{a}$ \\
\hline $\mathrm{pH}$ & $7.28 \pm 0.42 \mathrm{a}$ & $0.345 \pm 0.08 \mathrm{a}$ & $0.331 \pm 0.06 \mathrm{a}$ \\
\hline $\mathrm{EC}\left(\mathrm{ms} \mathrm{cm}^{-1}\right)$ & $0.337 \pm 0.05 \mathrm{a}$ & $0.214 \pm 0.05 \mathrm{a}$ & $0.201 \pm 0.04 \mathrm{a}$ \\
\hline $\mathrm{TDS}\left(\mathrm{g} \mathrm{L}^{-1}\right)$ & $0.209 \pm 0.03 \mathrm{a}$ & $0.15 \pm 0.04 \mathrm{a}$ & $0.14 \pm 0.03 \mathrm{a}$ \\
\hline Salinity $(\mathrm{ppt})$ & $0.15 \pm 0.02 \mathrm{a}$ & & \\
\hline
\end{tabular}

Table 4: Growth and yield of lettuce in response to different tilapia stocking densities in DRAPS conditions

\begin{tabular}{|c|c|c|c|}
\hline \multirow{2}{*}{ Growth and yield parameters } & \multicolumn{3}{|c|}{ Treatments } \\
\cline { 2 - 4 } & T1 & T2 & T3 \\
\hline Shoot fresh weight $\left(\right.$ g plant $\left.^{-1}\right)$ & $10.73 \pm 1.63 \mathrm{~b}$ & $9.46 \pm 0.466 \mathrm{~b}$ & $1.76 \pm 0.26$ a \\
\hline Root fresh weight $\left(\mathrm{g} \mathrm{plant}^{-1}\right)$ & $0.40 \pm 0.10 \mathrm{~b}$ & $0.48 \pm 0.15 \mathrm{~b}$ & $21.67 \pm 3.21 \mathrm{a}$ \\
\hline Number of leaves $\left(\right.$ number plant $\left.^{-1}\right)$ & $22 \pm 2.00 \mathrm{a}$ & $18.34 \pm 1.15 \mathrm{a}$ & $212.69 \pm 67.05 \mathrm{a}$ \\
\hline Leaf area $\left(\mathrm{cm}^{2}\right.$ plant & \\
\hline
\end{tabular}


Table 5: Growth and yield of tilapia reared for 52 days at different stocking densities under the DRAPS condition

\begin{tabular}{|c|c|c|c|}
\hline \multirow{2}{*}{ Fish yield Parameters } & \multicolumn{3}{|c|}{ Treatments } \\
\cline { 2 - 4 } & T1 & T2 & 2.8 \\
\hline Initial biomass (kg) & 4.2 & 3.5 & $5.357 \pm 81.66 \mathrm{c}$ \\
\hline Final biomass (kg) & $7.633 \pm 51.61 \mathrm{a}$ & $6.565 \pm 54.08 \mathrm{~b}$ & $2.557 \pm 81.63 \mathrm{c}$ \\
\hline WG (kg) & $3.433 \pm 51.60 \mathrm{a}$ & $3.065 \pm 54.08 \mathrm{~b}$ & $1.14 \pm 0.03 \mathrm{~b}$ \\
\hline FCR & $1.27 \pm 0.02 \mathrm{a}$ & $1.18 \pm 0.02 \mathrm{~b}$ & $97.05 \pm 2.61 \mathrm{a}$ \\
\hline
\end{tabular}

\section{DISCUSSION}

Water quality parameters of the fish tank are crucial in APS as they will directly affect the growth, weight gain of the fish (Harmon 2009). In this study, the physical water quality parameters of the tanks, which were T, pH, DO, EC, TDS, and salinity, in all treatments fell within the recommended limits. In this study, the $\mathrm{T}$ was within the recommended range for tilapia between $27^{\circ} \mathrm{C}$ and $30^{\circ} \mathrm{C}$ (El-Sayed 2006; Delong et al., 2009). Besides $\mathrm{T}, \mathrm{pH}$ is also one of the most critical factors for the survival of the components in APS, which includes fish, microbes, and plants. Ross (2000) and Delong et al. (2009) and reported that the optimum $\mathrm{pH}$ for tilapia growth was between 6.0 and 9.0. With reference to that, the $\mathrm{pH}$ of the rearing tanks in this study fell within the range of 6.0 to 7.0, which was similar to the findings of that in Rakocy et al. (2006). Optimizing and maintaining the $\mathrm{pH}$ within the range of 6.0 to 7.0 can keep the ammonia in the form of $\mathrm{NH}_{4}^{+}$, thus lowering the toxicity level caused by the $\mathrm{NH}_{3}$. In APS, it is crucial to optimize the $\mathrm{T}$ and $\mathrm{pH}$ as both parameters correlate strongly to $\mathrm{NH}_{3}$ concentration. The $\mathrm{pH}$ of the water is not only a requirement for fish growth but also to ensure the availability of nutrients and allow optimum nutrient absorption by plants for effective plant growth and development in soilless culture systems. However, the $\mathrm{pH}$ levels in this study were higher than the optimum level for plant growth and development, as recommended by Resh (2012), which is between 5.5 and 6.5. The mean values of the water $\mathrm{T}$ in this study for both time intervals were higher than the recommended range for lettuce plant, that is, $20^{\circ} \mathrm{C}$ to $26^{\circ} \mathrm{C}$ (Resh 2012). Other than $\mathrm{T}$ and $\mathrm{pH}$, $\mathrm{DO}$ is also one of the most critical environmental factors linked to the proper physiological functions of tilapia and is a limiting factor for the lifespan of fish (Zhao et al., 2018; Li et al., 2018). In this study, it was observed that higher stocking density had a lower DO level. This observation is congruent with the findings of Mahfouz et al. (2015) and Zaki et al. (2020). The mean values of the DO obtained from this study were within the recommended range by Eding et al. (2009), which is between $4.0 \mathrm{mg} \mathrm{L}^{-1}$ and $6.0 \mathrm{mg} \mathrm{L}^{-1}$.

The chemical composition of the nutrient solution in the fish tanks was composed of dissolved ions and organic substances produced from the biological processes of nitrifying bacteria. In this study, it was observed that the concentrations of $\mathrm{NH}_{3}-\mathrm{N}, \mathrm{NH}_{4}, \mathrm{NO}_{2}-\mathrm{N}, \mathrm{NO}_{3}-\mathrm{N}$, and $\mathrm{K}$ increased in higher stocking density except for $\mathrm{P}$. According to Durborow et al. (1997), Hargreaves and Tucker (2004), Zaki et al. (2020), and Capkin et al. (2010), the accumulation of feces and $\mathrm{N}$ in the form of $\mathrm{NH}_{3}$ and $\mathrm{NO}_{2}$ will negatively affect the water quality. The TAN concentration for T2 and T3 was within the recommended value by Timmons et al. (2002), which is below $3.0 \mathrm{mg} \cdot \mathrm{L}^{-1}$ whereas that of $\mathrm{T} 1$ exceeded the recommended value. During the first week of the

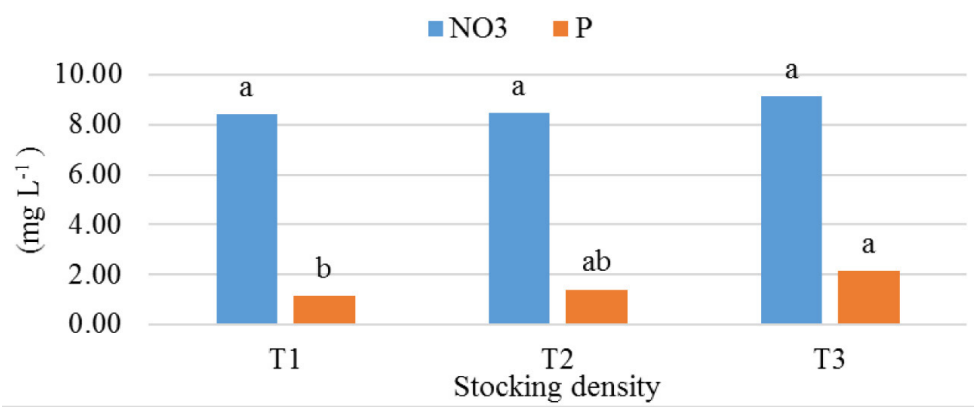

Figure 2. The concentration of nitrate and phosphorus per $1000 \mathrm{~g}$ feeding under three stocking density 
study period, the $\mathrm{NO}_{2}-\mathrm{N}$ concentration increased with the stocking density, and it was higher than that of the recommended value by Timmons et al. (2002), which is below $1.0 \mathrm{mg} \cdot \mathrm{L}^{-1}$. Additionally, DeLong et al. (2009) found out that the optimal $\mathrm{NO}_{2}-\mathrm{N}$ lower than $5 \mathrm{mg} \cdot \mathrm{L}^{-1}$. In DRPAS, $\mathrm{NO}_{3}-\mathrm{N}$ is also one of the most critical end products from the nitrification process. The $\mathrm{NO}_{3}-\mathrm{N}$ level in this study did not meet the optimum level of $\mathrm{NO}_{3}-\mathrm{N}$ for the growth of lettuce in HP recommended by Resh (2012), which is $165.0 \mathrm{mg} \cdot \mathrm{L}^{-1}$, but fell within the range of $26.3 \mathrm{mg} \cdot \mathrm{L}^{-1}$ to $42.0 \mathrm{mg} \cdot \mathrm{L}^{-1}$, which was the recommended range for APS by Rakocy et al. (2006). Also, the concentrations of $\mathrm{P}$ and $\mathrm{K}$ in this study did not fell within the recommended range for optimum lettuce growth by Resh (2012). However, studies by Adler et al. (1996), Seawright et al. (1998), and Graber and Junge (2009) reported that APS, which relies solely on fish waste as the source of nutrients for plants, had a lower concentration of $\mathrm{P}$ and $\mathrm{K}$. Hence, the inorganic $\mathrm{P}$ and $\mathrm{K}$ supplies in different types of APS become the main factor for optimum growth and development, resulting in the improvement of quality and quantity of plants. Furthermore, it was observed that the Fe production from the nitrification process was minimal. This phenomenon was supported by Adler et al. (1996), Rakocy et al. (2006), Graber and Junge (2009), Roosta and Hamidpour (2011), and Nozzi et al. (2018), who reported that $\mathrm{Fe}$ was one of the most limited micronutrients that were produced from the fish waste in APS. As such, throughout the entire period of this study, the effects of $\mathrm{Fe}$ deficiency, such as suppressed growth and leaf chlorosis, were observed. This condition was further explained by Briat (2007), which reported that Fe deficiency affected both of the plant's physiology and morphology by suppressing the growth of leaves, causing leaf chlorosis, and loss of turgidity. Kosegarten and Koyro (2001) also reported that $\mathrm{Fe}$ deficiency inhibited the formation of new leaves. In this study, the plant roots did not have any significant role in the removal of nutrients such as $\mathrm{NH}_{3}-\mathrm{N}, \mathrm{NH}_{4}^{+}$, and $\mathrm{NO}_{2}-\mathrm{N}$, which were toxic to the fish, from the first loop of the DRAPS because the plants were located in the second loop. Instead, the mechanical and biofilter tanks installed in the first loop played a major role in removing the toxic nutrients. Moreover, in contrast to SRAPS, the plant roots provided a surface area for the nitrifying bacteria to oxidize the toxic ammonia to nitrates. Fully developed roots have larger surface areas that can provide more space for the inhabitation of nitrifying bacteria. This catalyzes the nitrification process, which significantly lowered the concentration of $\mathrm{NH}_{3}-\mathrm{N}, \mathrm{NH}_{4}^{+}$, and $\mathrm{NO}_{2}-\mathrm{N}$ by converting them to soluble nitrates (Estim et al., 2018). Furthermore, Trang and Brix (2012) stated that (Canna glauca L.) can be used as a biofilter for removing $\mathrm{NH}_{4}-\mathrm{N}$ from the nitrification-denitrification process. Besides that, Moya et al. (2016) also suggested some herbs such as basil, peppermint, and spearmint as the biofilter in SRAPS. The results from these previous studies indicated that nitrifying bacteria were associated with the root surface area of the plants, and this maintained the water quality in SRAPS (Knaus and Palm 2017). While in DRAPS, the only advantage of having a larger root surface area is to increase the nutrients absorption rate of the lettuce.

In this study, three different stocking densities of tilapia were tested in order to observe its effects on lettuce growth in small-scale production. The main difference among the stocking densities was the concentrations of nutrients produced, which in turn, affected the growth and development of the lettuce. According to Pérez-Urrestarazu et al. (2019), the productivity of APS is highly dependent on the type of lettuce and environmental conditions. In this study, the air and water T, EC, and $\mathrm{pH}$ were not controlled and there were no external inorganic nutrients supplied to the HP units. In terms of lettuce yield in all the treatments, the observed shoot fresh weight, number of leaves, root fresh weight and leaf area were lower than the values reported in the studies conducted by Licamele (2009), Schmautz et al. (2017), Nozzi et al. (2018), and Madar et al. (2019). Being nitrate has a crucial role in determining the effectiveness of a DRAPS and determining the optimal growth of leafy plants such as lettuce. The high planting density of 32 plant $\cdot \mathrm{m}^{-2}$ together with the low nitrate level in all the treatments, has contributed to the poor growth performances of the lettuce. Rakocy et al. (2006) recommended the range from $26.3 \mathrm{mg} \cdot \mathrm{L}^{-1}$ to $42.0 \mathrm{mg} \cdot \mathrm{L}^{-1}$ as the optimum nitrate level for the healthy growth of leafy plants in APS. Regarding that, the nitrate levels in this study were between $26.13 \mathrm{mg} \cdot \mathrm{L}^{-1}$ and $36.7 \mathrm{mg} \cdot \mathrm{L}^{-}$ ${ }^{1}$, which fell within the recommended range. Despite that, the lettuce still ceased to grow. This can be explained by using the results of other water quality parameters such as $\mathrm{T}$ and $\mathrm{pH}$, which were not in the optimal range. The elevated $\mathrm{T}$ and $\mathrm{pH}$ 
may have contributed to the stunted growth of the lettuce by decreasing the absorption of the nutrients. During the period of vegetative growth in this study, the Fe deficiency symptoms (chlorosis and suppressed growth) began to be visible on the new lettuce leaves in all the NFT units. According to Jones et al. (2005), the nutrient requirements for leafy plants such as lettuce increases with time during vegetative growth. However, the concentrations of the nutrients $(\mathrm{N}, \mathrm{P}, \mathrm{K}, \mathrm{Mg}, \mathrm{Ca}$, and $\mathrm{Fe}$ ) that were produced in the first loop were extremely low and in turn, stunted the growth of lettuce. Regarding this, Rakocy et al. (2007) also stated that low yield in APS might be associated with low $\mathrm{K}, \mathrm{P}, \mathrm{Fe}$, and $\mathrm{Mn}$ concentrations in the nutrient solution. Nozzi et al. (2018) also reported that P deficiency in APS led to low nitrogen uptake by lettuce. One of the main limitations when comparing the yields of lettuce in APS is that the background data, such as the lettuce type, seedling age, planting density, and growth period, are not available. Besides, optimization of physical water quality like $\mathrm{T}$ and $\mathrm{pH}$ to ensure nutrients availability in APS is a complex process.

The stocking density of tilapia is one of the most significant factors that have direct impacts on the weight gain, behavior and yield in APS. The tilapia were gaining more weight in higher stocking density. While, the FCR values ranged between 1.14 and 1.27, which were similar to the productive recirculating aquaculture performance with an FCR value of 1.25 reported by El-Sayed (2006) and Timmons and Ebeling (2013). Besides, the FCR values in this study were lower and more preferable than those reported by Rakocy et al. (2006), which were between 1.70 to 1.80 . The SR of tilapia was higher in lower stocking density, which was within the normal range for tilapia as reported by El-Sayed (2006).

\section{CONCLUSION}

The results showed that the stocking density of fish had impacted the tilapia growth, water quality and production of lettuce. The lowest stocking density of gave the highest yield of lettuce. The uncontrolled temperature and $\mathrm{pH}$, along with the low nitrogen, phosphorus, potassium and iron concentrations, were the major reasons for the low growth and yield of lettuce. This study approves the importance of supplementing inorganic nutrients and optimizing the $\mathrm{pH}$ in decoupled recirculation aquaponic systems. This study validated that decoupled recirculation aquaponic systems that relied solely on fish waste have a low concentration of elements such as nitrate, phosphorus, potassium and iron to supply nutrients for plants in contrast to hydroponics. The total fish biomass yield and weight gain, feed conversion ratio increased in higher stocking density. Finally, considering the specific decoupled recirculation aquaponic systems design used in this study, the lettuce roots did not play any role in removing ammonia, ammonium, and nitrite, but only for nutrients uptake.

\section{REFERENCES}

1. Adler, P., Takeda, F., Glenn, D., \& Summerfelt, S. 1996. Utilizing byproducts to enhance aquaculture sustainability. World Aquaculture, 27(2), 24-26.

2. Ajitama, P., Effendi, H., \& Hariyadi, S.2018. Usage of fisheries rearing waste for butterhead lettuce (Lactuca sativa L. var. capitata) cultivation in recirculation. Nature Environment and Pollution Technology, 17(1), 145-151.

3. Blanchard, C., Wells, D. E., Pickens, J. M., \& Blersch, D. M. 2020. Effect of $\mathrm{pH}$ on Cucumber Growth and Nutrient Availability in a Decoupled Aquaponic System with Minimal Solids Removal. Horticulturae, 6(1), 10.

4. Briat, J. F., Curie, C., \& Gaymard, F.2007. Iron utilization and metabolism in plants. Current opinion in plant biology, 10(3), 276-282. https://doi. org/10.1016/j.pbi.2007.04.003

5. Brown, S., McIvor, K., \& Snyder, E. H. (Eds.) .2016. Sowing seeds in the city: Ecosystem and municipal services. Dordrecht: Springer

6. Buzby, K. M., \& Lin, L. S.2014. Scaling aquaponic systems: Balancing plant uptake with fish output. Aquacultural Engineering, 63, 39-44. https://doi. org/10.1016/j.aquaeng.2014.09.002

7. Capkin, E., Kayis, S., Boran, H., \& Altinok, I. 2010. Acute toxicity of some agriculture fertilizers to rainbow trout. Turkish Journal of Fisheries and Aquatic Sciences, 10(1), 19-25. https://doi.org/10.4194/ trjfas.2010.0103

8. Delaide, B., Goddek, S., Gott, J., Soyeurt, H., \& Jijakli, M. H.2016. Lettuce (Lactuca sativa L. var. Sucrine) growth performance in complemented aquaponic solution outperforms hydroponics. Water, 8(10), 467. https://doi.org/10.3390/w8100467

9. DeLong, P.D., Losordo, M.T. and Rakocy, J.E.2009. Tank Culture of Tilapia. SRAC Publication, No. 282, Texas, USA, 7 pp 
10. Eding, E. H., Kamstra, A., Verreth, J. A. J., Huisman, E. A., \& Klapwijk, A.2006. Design and operation of nitrifying trickling filters in recirculating aquaculture: a review. Aquacultural engineering, 34(3), 234-260. https://doi.org/10.1016/j. aquaeng.2005.09.007

11. Ebeling, J. M., Timmons, M. B., \& Bisogni, J. J.2006. Engineering analysis of the stoichiometry of photoautotrophic, autotrophic, and heterotrophic removal of ammonia-nitrogen in aquaculture systems. Aquaculture, 257(1-4), 346-358. https://doi. org/10.1016/j.aquaculture.2006.03.019

12. El-Sayed, A.-F.M. Tilapia Culture; CABI Publishing: Oxfordshire, UK, 2006.

13. Emerson, K., Russo, R.C., Lund, R.E. and Thurston, R.V.1975. Aqueous ammonia equilibrium calculations: effect of $\mathrm{pH}$ and temperature. Journal of the Fisheries Board of Canada, 32(12), pp.2379-2383.

14. Endut, A., Jusoh, A., Ali, N., Nik, W. W., \& Hassan, A.2010. A study on the optimal hydraulic loading rate and plant ratios in recirculation aquaponic system. Bioresource technology, 101(5), 1511-1517. https://doi.org/10.1016/j.biortech.2009.09.040

15. Espinosa Moya, E. A., Angel Sahagún, C. A., Mendoza Carrillo, J. M., Albertos Alpuche, P. J., Álvarez-González, C. A., \& Martínez-Yáñez, R.2016. Herbaceous plants as part of biological filter for aquaponics system. Aquaculture Research, 47(6), 1716-1726. https://doi.org/10.1111/are.12626

16. Estim, A., Saufie, S., \& Mustafa, S.2019. Water quality remediation using aquaponics sub-systems as biological and mechanical filters in aquaculture. Journal of Water Process Engineering, 30, 100566. https://doi.org/10.1016/j.jwpe.2018.02.001

17. Geisenhoff, L. O., Jordan, R. A., Santos, R. C., Oliveira, F. C. D., \& Gomes, E. P. 2016. Effect of different substrates in aquaponic lettuce production associated with intensive tilapia farming with water recirculation systems. Engenharia Agrícola, 36(2), 291-299. https://doi.org/10.1590/1809-4430-Eng. Agric.v36n2p291-299/2016.

18. Graber, A., \& Junge, R. 2009. Aquaponic Systems: Nutrient recycling from fish wastewater by vegetable production. Desalination, 246(1-3), 147-156. https://doi.org/10.1016/j.desal.2008.03.048

19. Hargreaves, J.A. and Tucker, C.S.2004. Managing ammonia in fish ponds (Vol. 4603). Stoneville, MS: Southern Regional Aquaculture Center.

20. Harmon, T. S. 2009. Methods for reducing stressors and maintaining water quality associated with live fish transport in tanks: a review of the basics. Reviews in Aquaculture, 1(1), 58-66. https://doi. org/10.1111/j.1753-5131.2008.01003.x

21. Jimoh, W.A., Kamarudin, M.S., Sulaiman, M.A. and Dauda, A.B.2019. Assessment of prebiotic potentials in selected leaf meals of high dietary fibre on growth performance, body composition, nutrient utilization and amylase activities of a tropical commercial carp fingerlings. Aquaculture Research, 50(11), 3401-3411. https://doi.org/10.1111/ are. 14298

22. Jones, J. B., 2005. Hydroponics: a practical guide for the soilless grower. CRC Press

23. Jordan, R.A., Geisenhoff, L.O., Oliveira, F.C.D., Santos, R.C. and Martins, E.A. 2018a. Yield of lettuce grown in aquaponic system using different substrates. Revista Brasileira de Engenharia Agrícola e Ambiental, 22(1), 27-31. https://doi. org/10.1590/1807-1929/agriambi.v22n1p27-31

24. Jordan, R. A., Ribeiro, E. F., Oliveira, F. C. D., Geisenhoff, L. O., \& Martins, E. A.2018. Yield of lettuce grown in hydroponic and aquaponic systems using different substrates. Revista Brasileira de Engenharia Agrícola e Ambiental, 22(8), 525-529. https://doi.org/10.1590/1807-1929/agriambi. v22n8p525-529

25. Karimanzira, D., Keesman, K. J., Kloas, W., Baganz, D., \& Rauschenbach, T. 2016. Dynamic modeling of the INAPRO aquaponic system. Aquacultural engineering, 75, 29-45. https://doi.org/10.1016/j. aquaeng.2016.10.004

26. Kloas, W., Groß, R., Baganz, D., Graupner, J., Monsees, H., Schmidt, U., Staaks, G., Suhl, J., Tschirner, M., Wittstock, B. and Wuertz, S.2015. A new concept for aquaponic systems to improve sustainability, increase productivity, and reduce environmental impacts. Aquaculture Environment Interactions 7(2), 179-192. https://doi.org/10.3354/aei00146

27. Knaus, U., \& Palm, H. W. 2017. Effects of the fish species choice on vegetables in aquaponics under spring-summer conditions in northern Germany (Mecklenburg Western Pomerania). Aquaculture, 473,62-73. https://doi.org/10.1016/j. aquaculture.2017.01.020

28. Kosegarten, H., \& Koyro, H. W. 2001. Apoplastic accumulation of iron in the epidermis of maize (Zea mays) roots grown in calcareous soil. Physiologia plantarum, 113(4), 515-522. https://doi. org/10.1034/j.1399-3054.2001.1130410.x

29. Li, M., Wang, X., Qi, C., Li, E., Du, Z., Qin, J. G., \& Chen, L. 2018. Metabolic response of Nile tilapia (Oreochromis niloticus) to acute and chronic hypoxia stress. Aquaculture, 495, 187-195. https:// doi.org/10.1016/j.aquaculture.2018.05.031

30. Liang, J. Y., \& Chien, Y. H. 2013. Effects of feeding frequency and photoperiod on water quality and crop production in a tilapia-water spinach raft aquaponics system. International Biodeterioration \& Biodegradation, 85, 693-700. https://doi. org/10.1016/j.ibiod.2013.03.029

31. Licamele J. 2009. Biomass production and nutrient dynamics in an aquaponics system. $\mathrm{PhD}$ thesis. 
Department of Agriculture and biosystems engineering, University of Arizona

32. Love, D.C., Fry, J.P., Li, X., Hill, E.S., Genello, L., Semmens, K., Thompson, R.E.2015. Commercial aquaponics production and profitability: Findings from an international survey. Aquaculture. 435. 67-74. https://doi.org/10.1016/j. aquaculture.2014.09.023

33. Madar, Á.K., Rubóczki, T. and Hájos, M.T. 2019. Lettuce production in aquaponic and hydroponic systems. Acta Universitatis Sapientiae, Agriculture and Environment, 11(1),51-59. https://doi. org/10.2478/ausae-2019-0005

34. Mahfouz, M. E., Hegazi, M. M., El-Magd, M. A., \& Kasem, E. A.2015. Metabolic and molecular responses in Nile tilapia, Oreochromis niloticus during short and prolonged hypoxia. Marine and Freshwater Behaviour and Physiology, 48(5), 319-340. https://doi.org/10.1080/10236244.2015.1055915

35. Monsees, H., Kloas, W. and Wuertz, S. 2017. Decoupled systems on trial: Eliminating bottlenecks to improve aquaponic processes. PloS one, 12(9), p.e0183056. https://doi.org/10.1371/journal. pone. 0183056

36. Monsees, H., Suhl, J., Paul, M., Kloas, W., Dannehl, D. and Würtz, S.2019. Lettuce (Lactuca sativa, variety Salanova) production in decoupled aquaponic systems: Same yield and similar quality as in conventional hydroponic systems but drastically reduced greenhouse gas emissions by saving inorganic fertilizer. PLoS ONE 14(6): e0218368. https://doi.org/10.1371/journal.pone.0218368

37. Nozzi, V., Graber, A., Schmautz, Z., Mathis, A., \& Junge, R. 2018. Nutrient management in aquaponics: comparison of three approaches for cultivating lettuce, mint and mushroom herb. Agronomy, 8(3), 27. https://doi.org/10.3390/agronomy 8030027

38. Pérez-Urrestarazu, L., Lobillo-Eguíbar, J., Fernández-Cañero, R., \& Fernández-Cabanás, V. M.2019. Suitability and optimization of FAO's small-scale aquaponics systems for joint production of lettuce (Lactuca sativa) and fish (Carassius auratus). Aquacultural Engineering, 85, 129-137. https://doi. org/10.1016/j.aquaeng.2019.04.001

39. Durborow, R. M., Crosby, D. M., \& Brunson, M. W. 1997. Nitrite in fish ponds. Southern Regional Aquaculture Center. SRAC Publication No. 462. http://www.aces.edu/dept/fisheries/aquaculture/ pdf/462fs.pdf

40. Rakocy, J.E, Shultz, R.C., Bailey, D.S., Thoman, E.S. 2004. Aquaponic production of tilapia and basil: comparing a batch and staggered cropping system. Acta Horticulturae. (ISHS) 648:63-69. https:// doi.org/10.17660/ActaHortic.2004.648.8

41. Rakocy, J.E., Masser, M.P., Losordo, T.M.2006. Recirculating aquaculture tank production systems: aquaponics-integrating fish and plant culture. SRAC publication, 454, 1-16.

42. Rakocy, J.2007. Ten Guidelines for Aquaponic Systems. Aquaponics Journal, 46, 14-17. Retrieved from $\mathrm{http} / /$ santarosa.ifas.ufl.edu/wp-content/uploads/2013/06/Aquaponics-Journal-10-Guidelines. pdf.

43. Rakocy, J.E. 2012. Aquaponics: integrating fish and plant culture. Aquaculture production systems, 1, 344-386. https://doi.org/10.1002/9781118250105. ch14

44. Resh,H.M.2012.HydroponicFoodProduction:ADefinitive Guidebook for the Advanced Home Gardener and the Commercial Hydroponic Grower. Boca Raton, Florida: CRC Press. Retrieved from http://howardresh.com/dr-howard-resh-hydroponic-services/ hydroponic-lettuce-production-i/

45. Resh, H.M. 2013. Hydroponic food production: a definitive guidebook for the advanced home gardener and the commercial hydroponic grower. CRC Press.

46. Roosta, H. R., \& Hamidpour, M. 2011. Effects of foliar application of some macro- and micro-nutrients on tomato plants in aquaponic and hydroponic systems. Scientia Horticulturae, 129(3), 396-402. https://doi.org/10.1016/j.scienta.2011.04.006

47. Ross, L.G .2000. Environmental physiology and energetics. In Tilapias: Biology and Exploitation; McAndrew, B.J., Ed.; Springer Netherlands: Dordrecht, The Netherlands,89-128

48. Schmautz, Z., Graber, A., Jaenicke, S., Goesmann, A., Junge, R., \& Smits, T. H. 2017. Microbial diversity in different compartments of an aquaponics system. Archives of microbiology, 199(4), 613-620. https://doi.org/10.1007/s00203-016-1334-1

49. Seawright, D.E., Stickney, R. R., \& Walker, R. B .1998. Nutrient dynamics in integrated aquaculture-hydroponics systems. Aquaculture, 160(3-4), 215-237. https://doi.org/10.1016/ S0044-8486(97)00168-3

50. Silva, L., Escalante, E., Valdés-Lozano, D., Hernández, M. and Gasca-Leyva, E. 2017. Evaluation of a semi-intensive aquaponics system, with and without bacterial biofilter in a tropical location. Sustainability, 9(4), 592. https://doi.org/10.3390/su9040592

51. Sreejariya, P., Raynaud, T., Dabbadie, L. and Yakupitiyage, A.2016. Effect of water recirculation duration and shading on lettuce (Lactuca sativa) growth and leaf nitrate content in a commercial aquaponic system. Turkish Journal of Fisheries and Aquatic Sciences, 16 (2): 311-319. http://dx.doi. org/10.4194/1303-2712-v16_2_11

52. Suhl, J., Dannehl, D., Kloas, W., Baganz, D., Jobs, S., Scheibe, G. and Schmidt, U.2016. Advanced aquaponics: Evaluation of intensive tomato production in aquaponics vs. conventional hydroponics. 
Agricultural Water Management, 178,.335-344. https://doi.org/10.1016/j.agwat.2016.10.013

53. Suhl, J., Dannehl, D., Baganz, D., Schmidt, U. and Kloas, W.2018a. An innovative suction filter device reduces nitrogen loss in double recirculating aquaponic systems. Aquacultural engineering, 82,.63-72. https://doi.org/10.1016/j.aquaeng.2018.06.008.

54. Suhl, J., Dannehl, D., Zechmeister, L., Baganz, D., Kloas, W., Lehmann, B., Scheibe, G. and Schmidt, U .2018b. Prospects and challenges of double recirculating aquaponic systems (DRAPS) for intensive plant production. Acta horticulturae. 1227, 449-456. https://doi.org/10.17660/ActaHortic.2018.1227.56.

55. Sveier, H., Raae, A.J. and Lied, E. 2000. Growth and protein turnover in Atlantic salmon (Salmo salar L.); the effect of dietary protein level and protein particle size. Aquaculture, 185(1-2), pp.101-120. https://doi.org/10.1016/S0044-8486(99)00344-0

56. Timmons, M.B., and Ebeling, J, M.2013. Recirculating Aquaculture (3rd ed.). Reading, United Kingdom: Ithaca Publishing Company. Retrieved from https://www.amazon.in/Recirculating-Aquaculture-3rd-Michael-Timmons/ $\mathrm{dp} / 0971264651$
57. Timmons, M.B., Ebeling, J.M., Wheaton, F.W., Summerfelt,S.T. \& Vinci, B.J.2002 Recirculating Aquaculture Systems (2nd Ed.). Cayuga Aqua Ventures, Ithaca, NY, Northeastern Regional Aquaculture Center Publication 01-002

58. Trang, N. T, D., and Brix, H. 2014. Use of planted biofilters in integrated recirculating aquaculturehydroponics systems in the Mekong Delta, Vietnam. Aquac Res, 45: 460-469. https://doi:10.1111 jj.1365-2109.2012.03247.

59. Zaki, M.A., Alabssawy, A.N., Nour, A.E.A.M., El Basuini, M.F., Dawood, M.A., Alkahtani, S. and Abdel-Daim, M.M. 2020. The impact of stocking density and dietary carbon sources on the growth, oxidative status and stress markers of Nile tilapia (Oreochromis niloticus) reared under biofloc conditions. Aquaculture Reports, 16, p.100282. https:// doi.org/10.1016/j.aqrep.2020.100282

60. Zhao, Z., Dong, S. and Xu, Q. 2018. Respiratory response of grass carp Ctenopharyngodon idellus to dissolved oxygen changes at three acclimation temperatures. Fish physiology and biochemistry, 44(1), pp.63-71. https://doi.org/10.1007/ s10695-017-0413-9 